\title{
Diet of dominant frugivorous bat species in an oil palm landscape from Colombian Llanos: implications for forest conservation and recovery
}

\author{
María Alejandra Cely-Gómez ${ }^{*}$ and Dennis Castillo-Figueroa ${ }^{1}$
}

\begin{abstract}
${ }^{1}$ Pontificia Universidad Javeriana, Facultad de Estudios Ambientales y Rurales, Departamento de Ecología y Territorio, Carrera de Ecología. Carrera 743 82, Bogotá. 11001000. Colombia. Email: alejandracelygomez@gmail.com (MACG), dennis.castillof@ gmail.com (DCF).

*Corresponding autor
\end{abstract}

\begin{abstract}
Oil palm plantations have become a major agricultural landscape in the Neotropics, especially in Colombia, the largest oil palm producer in the region. The Orinoco, or Llanos, region of eastern Colombia is predicted to increase expansion for palm oil acreage over the coming decades, with implications for biodiversity loss. Describing dietary diversity of frugivorous bats is a functional approach to understanding the effect of oil palm dominated landscapes on bat-fruit interactions. Our objective was to characterize the diet of the dominant (most abundant) bat species present in an oil palm landscape from the Colombian Llanos. We compared diet breadth of bat species on the basis of Levin's index and we assessed differences in the frequency of seed consumption through Chi-square tests $\left(\chi^{2}\right)$. We calculated diet overlap with a MorisitaHorn index. We characterized diet breadth and overlap for four taxa (three species and one species complex) of bats from 149 fecal samples and 344 individual bats, from which we identified 13 seed species. Dietary composition differed significantly among bat species, as did diet breadth. Diet breadth was highest in Carollia spp. and lowest in Sturnira lilium. The greatest degree of diet overlap ocurred between Artibeus lituratus and A. planirostris and the lowest overlap between S. lilium and all the other species. Considering the functional identity of the plants dispersed by bats in our sample, where most of them are pioneer species that colonize disturbed areas, it is fundamental to preserve habitats such as forest fragments that maintain bat assemblages with diverse diets in agriculturally disturbed landscapes. This may have important implications in future restoration process at these sites.
\end{abstract}

Las plantaciones de palma aceitera se han convertido en uno de los principales paisajes agrícolas en el Neotrópico, especialmente en Colombia, el mayor productor de palma de aceite en esta región. La Orinoquía, o llanos, región oriental de Colombia, es una de las principales áreas de expansión de este cultivo para las próximas décadas, con posibles implicaciones para la pérdida de biodiversidad. La descripción de la dieta de los murciélagos frugívoros aporta un enfoque funcional para comprender el efecto de los paisajes dominados por la palma aceitera en las interacciones murciélago-fruto. Nuestro objetivo fue caracterizar la dieta de las especies dominantes presentes en un paisaje de producción de palma de aceite en los Llanos Colombianos. Comparamos la amplitud de la dieta de las especies de murciélagos usando el índice de Levins y también evaluamos las diferencias en la frecuencia de consumo de semillas a través de la prueba Chi-cuadrado $\left(\chi^{2}\right)$. Para evaluar la superposición de la dieta entre las especies, calculamos el índice Morisita-Horn. Caracterizamos la amplitud y sobreposición de la dieta de cuatro taxa (tres especies y un complejo de especies) de murciélagos con 149 muestras fecales de 344 individuos, en las cuáles identificamos 13 especies de semillas. La composición y amplitud de la dieta varió significativamente entre especies de murciélagos. La amplitud de la dieta fue mayor para Carollia spp. y menor para Sturnira lilium. El mayor grado de solapamiento de dieta se presenta entre Artibeus lituratus y A. planirostris y el menor entre S. lilium y todas las demás especies. Considerando la identidad funcional de las plantas dispersadas por los murciélagos en nuestra muestra, donde la mayoría son especies pioneras que colonizan hábitats perturbados, es fundamental preservar fragmentos de bosques que mantienen conjuntos de murciélagos con diversas dietas en los paisajes agrícolas. Esto puede tener implicaciones importantes en el proceso de restauración futura en estos sitios.

Key words: Agricultural landscape; Chiroptera; Colombia; ecosystem services; oil palm; Orinoquia.

C 2019 Asociación Mexicana de Mastozoología, www.mastozoologiamexicana.org

\section{Introduction}

One of the main attributes of an ecological niche is the feeding resource associated with the species (Patterson et al. 2003). For bats, this component is one of the principal mechanisms associated with resource partitioning within assemblages (Giannini and Kalko 2004; Sánchez and Giannini 2018). Importantly, bats are known dispersers of seeds, and owing partly to their degree of diet specialization, maintaining intact bat assemblages has important implications for forest restoration and recovery following disturbance (Reid et al. 2015). For instance, within Neotropical frugivorous bats, species of the genera Artibeus, Carollia and Sturnira seem to specialize on different fruit species (Fleming 1986; Giannini and Kalko 2004; Saldaña-
Vázquez 2014; Saldaña-Vázquez et al. 2015). Thus, 67 \% of the Artibeus diet is composed of Ficus and Cecropia fruit, 60 $\%$ of the Carollia diet is made up of Piper fruit, and more than $50 \%$ of the Sturnira diet is composed of Solanum fruit (Saldaña-Vázquez et al. 2013). Nevertheless, this pattern has been described mainly in tropical moist forests (Fleming 1986; Giannini and Kalko 2004; Lobova et al. 2009), and current studies conducted in other Neotropical ecosystems have shown different dietary characteristics (Ríos-Blanco and Pérez-Torres 2015).

The Orinoco region of Colombia, also known as the Eastern Llanos, holds 114 bat species, which represent $55 \%$ of the species in the country (Pardo and Rangel 2014). Oil palm has become a main agricultural activity in this region, 
with palm plantations covering 206,559 ha $(40.3 \%$ of palm production of the country; Fedepalma 2017). Moreover, since current government projections suggest an expansion of oil palm cultivation in Colombia to approximately 1,000,000 ha in 2020 (Ministerio de Agricultura y Desarrollo Rural 2006), oil palm coverage probably will increase in the future. However, studies related to the impact of oil palm agriculture on biodiversity are scarce for the country (Pardo et al. 2015).

Considering the future restoration planning required by the government after oil palm production (Ministerio de Ambiente y Desarrollo Sostenible 2015), dietary analysis is an important step toward understanding the future seed rain in these environments, which will influence the local vegetation of early successional ecosystems (Mikich 2002; López and Vaughan 2007). Our objective was to characterize the diets of the dominant frugivorous bat species, Artibeus lituratus, A. planirostris, Carollia spp., and Sturnira lilium, in an oil palm landscape from the Colombian Llanos.

\section{Materials and methods}

Study area. The study was carried out in Hacienda La Cabaña plantation, an oil palm agricultural area of 2,200 ha from Cumaral municipality, in Meta Department, situated in the Llanos Orientales Region of Colombia (centroid of study area: $4^{\circ} 18^{\prime} 18.4^{\prime \prime} \mathrm{N},-73^{\circ} 21^{\prime} 26.5^{\prime \prime} \mathrm{W}$ ), between 310 and 368 meters elevation. Included in this landscape mosaic are remnants of primary and secondary forest, cattle pastures, and gallery forest along waterways.

Bat sampling. During January and February 2016 (at the end of the dry season), three palm crops of different height categories $(5,15$, and $20 \mathrm{~m}$ ) and one secondary forest in the palm matrix were selected for bat sampling. Due to the heterogeneity between the heights of palms and forest, a stratified sampling was carried out where the strata corresponded to the coverages: palm (5, 15 and 20 meters of height) and the forest. In each coverage seven mist nets ( $6 \times 3$ meters and $9 \times 3$ meters) were placed separated by at least 5 meters from each other using as a reference the furrows and palms arrangements in the crop, for three consecutive nights. We opened mist nets between 18:00 and 6:00 hr to capture bats. We individually marked each bat punch-marking numbers into their wing membranes with tattoo pliers for small domestic animals, to avoid repeat fecal samples from individuals. The total sampling effort was of $1,620 \mathrm{~m}^{2}$ mist-net hrs.

We evaluated Carollia perspicillata and C. brevicauda together as Carollia spp., due to the difficulty of taxonomic identification of the species. This does not affect data analysis due to the known phylogeny in dietary specialization in frugivorous bats (Giannini and Kalko 2004; SaldañaVázquez 2014; Sánchez and Giannini 2018).

We obtained fecal samples two ways. First, after capture, frugivorous bats were placed in a cloth bag for approximately 30 minutes to collect fecal samples. Sec- ond, we placed a plastic sheet below mist nets to collect the feces that fell to the ground at the time of capture. Plastic sheets were cleaned every 30 minutes, each time mist nets were checked. Fecal samples were stored in Eppendorf tubes with $70 \%$ alcohol, labeled with the individual's capture code, and processed according to Mello et al. (2004). The seeds were identified from comparisons with the seed collection of the Museo Javeriano de Historia Natural from Pontificia Universidad Javeriana (Bogotá, Colombia; MPUJ-MAMM-S), and seed taxonomic keys (e. g., Lobova et al. 2009; Linares and Moreno-Mosquera 2010).

Data analysis. The representativeness of seed species richness was calculated using Chao 2, which is a non-parametric estimator that provides the least biased estimates for small numbers of samples (Colwell and Coddington 1994), as in this study. Chao 2 also avoids problems related to detection probabilities and abundance estimation using incidence data (Pardo et al. 2018). For this, accumulation curves of observed species were constructed, and the count of new species was modeled with respect to the unit of sampling, the value of the estimated richness is the asymptote of the curve. The unit of sampling consisted of the fecal samples. To eliminate the effect of the order in which each fecal sample was added, we randomized sample order $(n=100)$ using EstimateS 9.1 (Colwell 2013). The representativeness percentage of seed species richness was calculated based on the richness estimated of Chao 2 estimator.

Regarding dietary analysis, we calculated the proportion of the consumption of seed species by the frugivorous bats based on the number of presences of each seed species in the total amount of fecal samples of each bat species. To determinate if the frequency of seeds consumed differed among the four bat taxa, we applied Chi-square tests $\left(\chi^{2}\right)$, using a level of significance of 0.05 . Levin's index was used to describe the diet breadth of all the species (Levins 1968). We used Hulbert's (1978) correction, to scale the diet breadth from 0 to $1\left(B_{\mathrm{a}}\right)$, facilitating comparisons among species. In this scale, the value 0 represents that all individuals of a species consume the same food species (more specialist) and the value 1 indicates that all individuals consume the totality of food items that are available, more generalist (Hulbert 1978). Finally, we used the Morisita-Horn index to test diet overlap among frugivorous species (Horn 1966).

\section{Results}

Frugivorous bat assemblage. We captured 393 individuals from 18 species and three families. Carollia spp. was the most abundant taxon, followed by $A$. planirostris, A. lituratus and S. lilium (Table 1), from the four taxa 149 fecal samples were obtained. These frugivorous bat species constituted $87.5 \%$ of the total individuals captured.

Diet of frugivorous bats. A total of 13 plant species along with two undetermined morphospecies were found in the 
Table 1. Bat abundance, seed species richness and Levin's index for frugivorous bat taxa found in Hacienda La Cabaña, Meta, Colombia. Proportion of total captures is given for the four dominant taxa.

\begin{tabular}{lrrr}
\hline \multicolumn{1}{c}{ Species } & Bat abundance & Seed species & Levin's index \\
\hline Artibeus lituratus & $14(3.56 \%)$ & 4 & 1.80 \\
Artibeus planirostris & $86(21.88 \%)$ & 9 & 2.63 \\
Carollia spp. & $233(59.28 \%)$ & 14 & 5.59 \\
Sturnira lilium & $11(2.79 \%)$ & 1 & 1 \\
Remaining bat species & 14 species $(12.49 \%)$ & 4 & \\
\hline
\end{tabular}

fecal samples (Figure 1; Table 2). According to the Chao 2, we obtained a completeness over the $85 \%$ of the seed species in our study (Figure 2 ) indicating an adequate sample with $93 \%$ of representativeness of the majority of seed species (Sobs $=16$; Chao2 mean $=17.19$; Chao $2 \mathrm{SD}= \pm 1.83$ ). The most important plant species in bat diets were Cecropia peltata, Vismia macrophylla and Solanum aff.jamaicence (Table 2). The composition and amount of seed consumption was quite different among bat species $\left(\chi^{2}=89.96\right.$, d. $f_{\text {. }}=$ 48, $P<0.05$; Figure 3). Carollia spp. had the broadest diet $\left(B_{\mathrm{a}}\right.$ $=0.353)$, followed by $A$. planirostris $\left(B_{a}=0.125\right)$, A. lituratus $\left(B_{\mathrm{a}}=0.06\right)$ and $\mathrm{S}$. lilum $\left(B_{\mathrm{a}}=0.007\right)$. The highest diet overlap was between $A$. planirostris and $A$. lituratus, followed by the Artibeus and Carollia species (Table 3).

\section{Discussion}

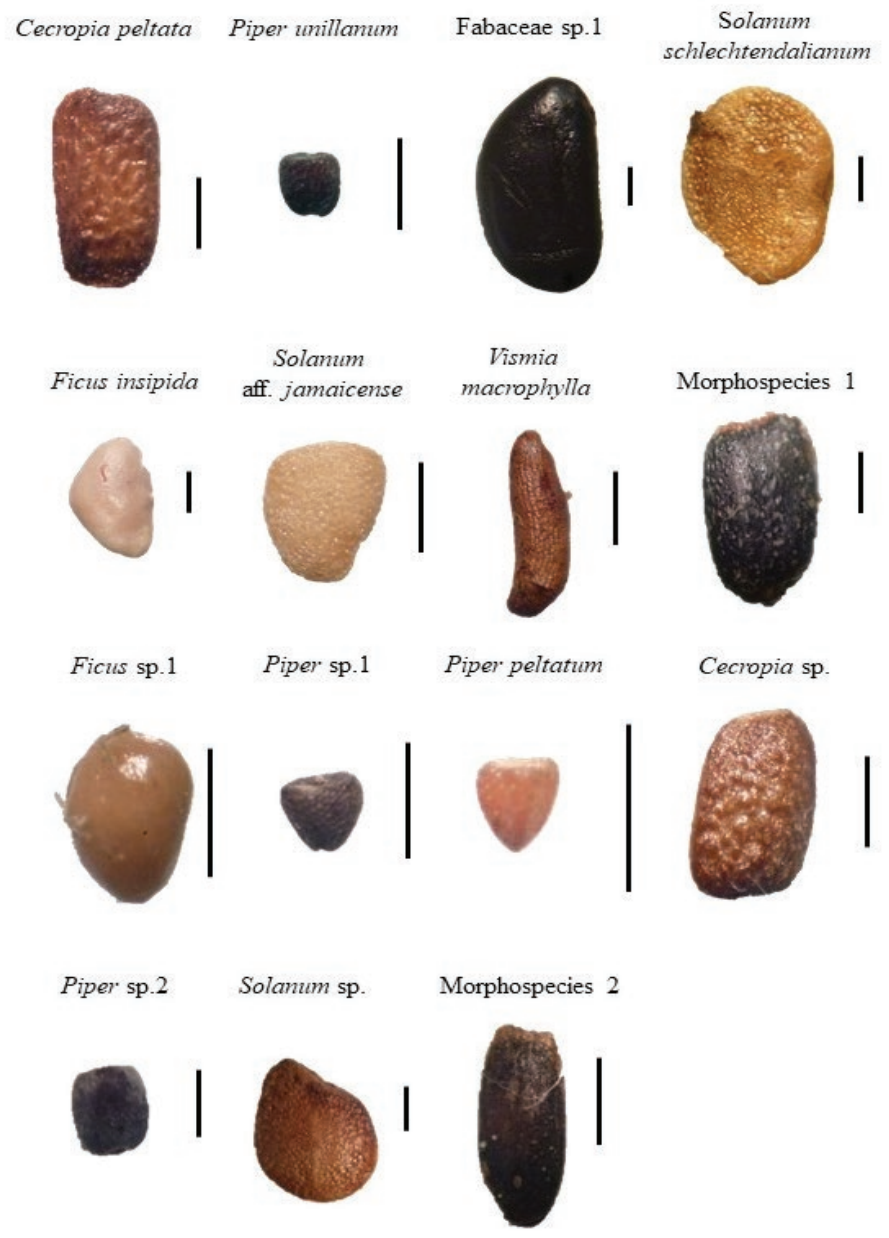

Figure 1. Photographs of seeds consumed by frugivorous bat species in Hacienda La Cabaña (Meta, Colombia). Scale bars $=1 \mathrm{~mm}$.
Table 2. Percentage of plant species occurrence for four frugivorous bat species in Hacienda La Cabaña, Meta, Colombia.

\begin{tabular}{|c|c|c|c|c|c|}
\hline \multirow{2}{*}{ Family } & \multirow{2}{*}{ Plant species } & \multicolumn{4}{|c|}{ Bat species } \\
\hline & & A. lituratus & A. planirostris & Carollia spp. & S. Iillium \\
\hline \multirow[t]{2}{*}{ Urticaceae } & Cecropia peltata & 72.73 & 60.53 & 18.10 & $\overline{0}$ \\
\hline & Cecropiasp. & 0 & 2.63 & 0.86 & 0 \\
\hline \multirow[t]{2}{*}{ Moraceae } & Ficus insipida & 9.09 & 13.16 & 1.72 & 0 \\
\hline & Ficus sp. & 0 & 10.53 & 2.59 & 0 \\
\hline \multirow[t]{4}{*}{ Piperaceae } & Piper unillanum & 9.09 & 2.63 & 11.21 & 0 \\
\hline & Piper sp. 1 & 0 & 2.63 & 6.90 & 0 \\
\hline & Piper peltatum & 0 & 2.63 & 4.31 & 0 \\
\hline & Piper sp. 2 & 0 & 0 & 0.86 & 0 \\
\hline Clusiaceae & Vismia macrophylla & 0 & 2.63 & 27.59 & 0 \\
\hline \multirow[t]{3}{*}{ Solanaceae } & Solanum aff.jamaicense & 9.09 & 2.63 & 21.55 & 0 \\
\hline & S. schlechtendalianum & 0 & 0 & 0.86 & 0 \\
\hline & Solanum sp. & 0 & 0 & 0 & 100 \\
\hline \multirow[t]{3}{*}{ Fabaceae } & Fabaceae sp. 1 & 0 & 0 & 1.73 & 0 \\
\hline & Morphospecies 1 & 0 & 0 & 0.86 & 0 \\
\hline & Morphospecies 2 & 0 & 0 & 0.86 & 0 \\
\hline
\end{tabular}

Diet variation among frugivorous bats. Differences in diet observed in this study, combined with low diet overlap (Table 2, Table 3, Figure 3), suggest niche segregation as a strategy to avoid competition among bat genera in our study area (López and Vaughan 2007; Saldaña-Vázquez 2014; Sánchez and Giannini 2018). We found that the main component of S. Iilium diet was Solanum, a finding supported by prior studies (Fleming et al. 1986; Giannini and Kalko 2004; Saldaña-Vázquez 2014). In contrast, we observed a high incidence of Cecropia in the diet of $A$. planirostris and $A$. lituratus, bats previously reported to feed heavily on Ficus (Mikich 2002; Ríos-Blanco and Pérez-Torres 2015). This is not unexpected, as phyllostomid bats shift diet between plant genera depending on their availability (Fleming et al. 1986; Giannini and Kalko 2004; Gonçalves da Silva et al. 2008; Saldaña-Vázquez 2014). Similarly, Carollia had a low consumption of Piper and Ficus in this study and a high incidence of Vismia, contrary to previous studies that consider this bat genus as a specialist of Piper and Ficus fruits, which may represent $65 \%$ of its diet (Mikich 2002; López and Vaughan 2007; Gonçalves da Silva et al. 2008; Suárez-Castro and Montenegro 2015). In contrast to previous research (Andrade et al. 2013, Ríos-Blanco and PérezTorres 2015), we found a greater diet breadth for Carollia than Artibeus or Sturnira. These findings suggest a high trophic plasticity in the diet of Carollia according to the availability of food resources where this bat genus occurs (Mello et al. 2004). Even though a strong relationship between phylogeny and dietary specialization in frugivorous bats has been established (Giannini and Kalko 2004; SaldañaVázquez 2014; Sánchez and Giannini 2018), our results regarding a high diet breadth in Carollia may be related to the inclusion of more than one species of this genus in the diet analysis. Also, possibly indicating a specialization of each Carollia species on different food items when coexisting (York and Billings 2009).

Potential importance of bats to seed dispersal in oil palm 


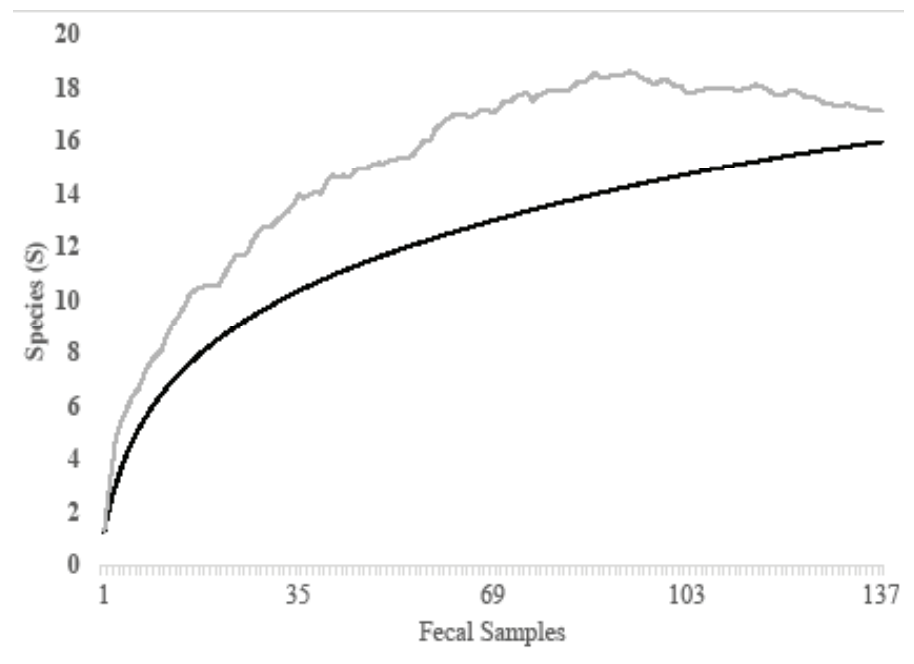

Figure 2. Accumulation curve of seed species consumed by frugivorous bat species at oil palm dominated landscape in Hacienda La Cabaña (Meta, Colombia). Grey solid line indicates Chao 2 model; black solid line represents the number of observed seed species $(S=16)$.

landscapes. Because the plants dispersed after the production of oil palm areas will depend on the seed rain within this habitat, the dominant species of frugivorous bat ensemble will determine the role of the seed dispersal in this area (Smith and Knapp 2003; Ríos-Blanco and PérezTorres 2015). In this respect, the functional identity of the plants dispersed by the most abundant frugivores have important implications in the future restoration process, particularly so because most of them are pioneer plants.

Considering the restoration process that the government demands after the land oil palm production (Ministerio de Ambiente y Desarrollo Sostenible 2015), seed dispersal mediated by biotic agents is critical for facilitating the seed rain. Some studies highlight the relevance of seed dispersal provided by animals in terms of economic benefits compared to a man-made replacement of this service (Hougner et al. 2006). In this way, given the key role of bats in reforestation or restoration process, it is fundamental to preserve habitats that maintain bat popula-

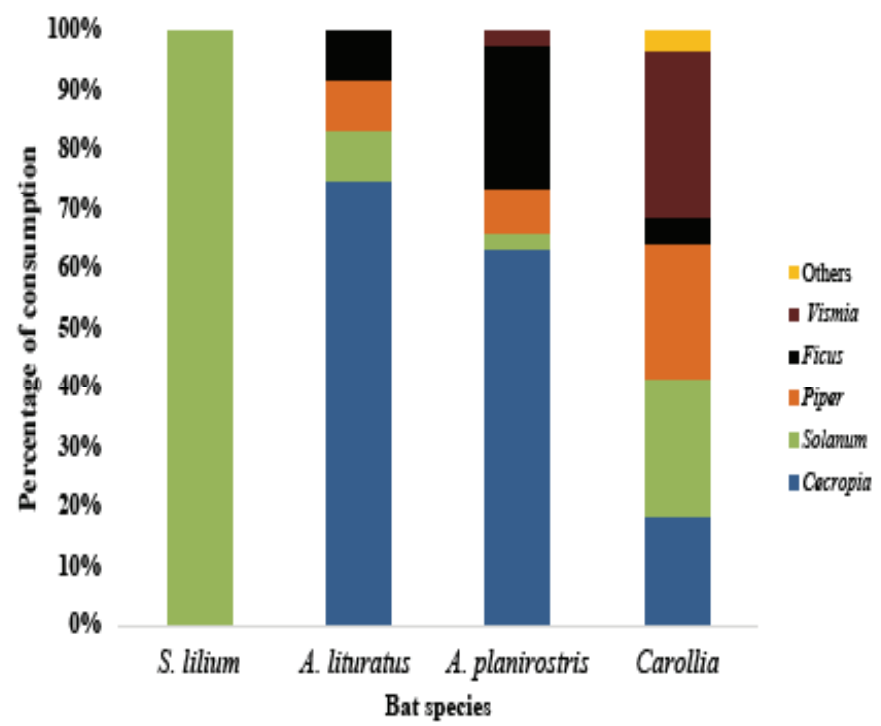

Figure 3. Proportion of consumption of each genus of plant by the different frugivorous bat species in Hacienda La Cabaña (Meta, Colombia).
Table 3. Diet overlap between four frugivorous bats species in oil palm dominated landscape in Hacienda La Cabaña, Meta, Colombia.

\begin{tabular}{lrrrr}
\hline & A. lituratus & A. planirostris & Carollia spp. & S. lilium \\
\hline A. lituratus & 1 & & & \\
A. planirostris & 0.95 & 1 & & \\
Carollia spp. & 0.43 & 0.45 & 1 & 1 \\
S. lilium & 0 & 0 & 0 & \\
\hline
\end{tabular}

tions such as forest fragments in agricultural landscapes (Burgar et al. 2015). Besides feeding resources, forest fragments provide shelter, feeding sites, roosts, and breeding opportunities for bat species (López and Vaughan 2007; Treitler et al. 2016). Therefore, conserving forest fragments and other similarly important landscape elements (e. g., shrubs, savannas, lagoons, grasslands), may enhance the restoration of agricultural areas, such as oil palm plantations. Although oil palm expansion is a cornerstone in the national agricultural development (Ministerio de Agricultura y Desarrollo Rural 2006), this productive system can be well-adapted to minimize ecological impacts on species (Ocampo-Peñuela et al. 2018). It is crucial to make a balance between the economic and environmental goals in order to produce oil palm with better management practices (Pardo and Campbell 2019).

\section{Acknowledgments}

We thank the Colombian federation of oil palm cultivators - Fedepalma for the interest and funding of this work. To Finca Hacienda La Cabaña for their accompaniment and willingness to logistically facilitate the completion of this work. To the members of the Functional Ecology Laboratory at Pontificia Universidad Javeriana for field trip and data processing collaboration. To J. Pérez-Torres for his comments during the early development of the project, J. $\mathrm{H}$. Castaño for the early revision of the manuscript, E. Stukenholtz and D. Anderson for the revision of the English version of the manuscript. Finally, two anonymous reviewers substantially improved the manuscript.

\section{Literature cited}

Andrade, T. Y., W. Thies, P. K. Rogerl, E. K. Kalko, and M. A. Mello. 2013. Hierarchical fruit selection by Neotropical leaf-nosed bats (Chiroptera: Phyllostomidae). Journal of Mammalogy 94:1094-1101.

BurgaR, J. M., M. D. CRAig, AND V. L. Stokes. 2015. The importance of mature forest as bat roosting habitat within a production landscape. Forest Ecology and Management 365:112-123.

ColwELL, R.K., AND J. CODDINGTON. 1994. Estimating terrestrial biodiversity through extrapolation. Philosophical transactions of the Royal Society of London. Series B. Biological Sciences Royal Society 345:101-118.

CoLwELL, R. K. 2013. EstimateS: Statistitcal Estimation of Species Richness and Shared Species from Samples (Software), Version 9.1. Avaliable: http://viceroy.colorado.edu/estimates/.

Fedepalma. 2017. Anuario estadístico: Principales cifras de la agroindustria palma de aceite en Colombia (2012-2016). Bogotá, Colombia. 
Fleming, T. H. 1986. Opportunism versus specialization: the evolution of feeding strategies in frugivorous bats. Pp. 105-118 in Frugivores and Seed Dispersal (Fleming, T. H., and A. Estrada eds.). Dr W Junk Publishers. Dordrecht, the Netherlands.

GIANNINI, N. P., AND E. K. KaLKo. 2004. Trophic structure in a large assemblage of Phyllostomid bats in Panama. Oikos 105:209-222.

Gonçalves da Silva, A., O. Gaona, and R. Medellín. 2008. Diet and trophic structure in a community of fruit-eating bats in Lacandon forest. Journal of Mammalogy 89:43-49.

HoRN, H. S. 1966. Measurement of "Overlap" in comparative ecological studies. American Naturalist 100:419-424.

Hougner, C., J. Colding, AND T. Soderovist. 2006. Economic value of a seed dispersal service in the Stockholm National Urban Park. Ecological Economics 59:364-374.

HULBERT, S. H. 1978. The measurement of niche overlap and some relatives. Ecology 59:67-77.

LEVIN, R. 1968. Evolution in changing environments. Princeton University Press. New Jersey, U. S. A.

Linares, E., and E. Moreno-Mosquera. 2010. Morphology of Crecopia (Crecopiaceae) fruitlets of the Colombian pacific and its taxonomic value in the bats diets study. Caldasia 32:275-287.

Lobova, T. A., C. K. Geiselman, And S. A. Mori. 2009. Seed dispersal by bats in the Neotropics. New York Botanical Garden and Michigan University Press. New York, U. S. A.

LÓPEZ, J.E., AND C. VAUGHAN. 2007. Food niche overlap among neotropical frugivorous bats in Costa Rica. Revista de Biología Tropical 55:301-313.

Mello, M. A. R., G. M. SchittinI, P. Selig, and H. D. G. Bergallo. 2004. Seasonal variation in the diet of the bat Carollia perspicillata (Chiroptera: Phyllostomidae) in an Atlantic forest area in southeastern Brazil. Mammalia 68:49-55.

MIKıCH, S. B. 2002. The diet of fruit-eating bats (Mammalia, Chiroptera, Phyllostomidae) in a small semideciduous seasonal forest remnant in south Brazil. Revista Brasileira de Zoologia 19:239-249.

Ministerio de Agricultura y Desarrollo Rural. 2006. Apuesta exportadora agropecuaria 2006 \pm 2020 . Consulted 8 September 2018. Available: http://www.mincit.gov.co.

Ministerio de Ambiente y Desarrollo Sostenible. 2015. Plan Nacional de Restauración. Consulted 5 September 2018. Available: http://www.minambiente.gov.co.

Ocampo-Peñuela, N., J. García-Ulloa, J. Ghazoul, and A. Etter. 2018. Quantifying impacts of oil palm expansion on Colombia's threatened biodiversity. Biological Conservation 224:117-121.

Pardo, L. E., W. F. Laurance, G. R. Clements, and W. Edwards. 2015. The impacts of oil palm agriculture on Colombia's biodiversity: what we know and still need to know. Tropical Conservation Science 88:828-845.

Pardo, L.E., M.J. Campbell, W. Edwards, G.R. Clements, and W.F. LAURANCE. 2018. Terrestrial mammal responses to oil palm dominated landscapes in Colombia. PLoS ONE 13: e0197539.

Pardo, L. E., AND M. CampBell. 2019. How oil palm can become more ecologically friendly. Australasian Science 40:35-37.

Pardo, A., AND J. O. RANGel-Ch. 2014. Mamíferos de la Orinoquia. Pp. 751-784 in Colombia Diversidad Biótica XIV (RangelCh, J. O. ed.). Universidad Nacional de Colombia. Bogotá, Colombia.
Patterson, B. D., M. R. Willig, and R. Stevens. 2003. Trophic strategies, niche partitioning, and patterns of ecology organization. Pp. 536-579 in Bat ecology (Kunz, T.H. and M. B. Fenton, eds.). University of Chicago Press. Chicago, U. S. A. Reid, J. L., C. D. Mendenhall, R. A. ZahaWI, and K. D. Holl. 2015. Scale dependent effects of forest restoration on Neotropical fruit bats. Restoration Ecology 23:681-689.

Ríos-Blanco, C., and J. Pérez-Torres. 2015. Dieta de las especies dominantes del ensamblaje de murciélagos frugívoros en un bosque seco tropical (Colombia). Mastozoología Neotropical 22:103-111.

Saldaña-Vazquez, R.A., V. J. Sosa, V.J., L.I. Iñiguez-Dávalos and J. E. Schondube. 2013. The role of extrinsic and intrinsic factors in Neotropical fruit bat-plant interactions. Journal of Mammalogy 94:632-639.

Saldaña-Vázquez, R. A. 2014. Intrinsic and extrinsic factors affecting dietary specialization in Neotropical frugivorous bats. Mammal Review 44:215-224.

Saldaña-Vázquez, R. A., E. Ruiz-Sanchez, L. Herrera-Alsina, and J. SCHONDUBE. 2015. Digestive capacity predicts diet diversity in Neotropical frugivorous bats. Journal of Animal Ecology 84:1-9.

SÁnchez, M. S., And N. P. GianninI. 2018. Trophic structure of frugivorous bats in the Neotropics: emergent patterns in evolutionary history. Mammal Review 48:90-107.

SMITH, M. D., AND A. K. KNAPP. 2003. Dominant species maintain ecosystem function with non-random species loss. Ecology Letters 6:509-517.

SuÁrez-CAstro, A., and O. Montenegro. 2015. Consumo de plantas pioneras por murciélagos frugívoros en una localidad de la Orinoquia Colombiana. Mastozoología Neotropical 22:125139.

Treitler, J. T., O. Heim, M. Tschapka, And K. Jung. 2016. The effect of local land use and loss of forests on bats and nocturnal insects. Ecology and Evolution 6:4289-4297.

YoRk H.A., S.A. BILLINGS. 2009 Stable-Isotope Analysis of Diets of Short-Tailed Fruit Bats (Chiroptera: Phyllostomidae: Carollia). Journal of Mammalogy, 90:1469-1477.

\section{Associated editor: Robert Owen}

Submitted: September 26, 2018; Reviewed: January 11, 2019;

Accepted:April 22, 2019; Published on line: May 6, 2019. 
154 THERYA Vol. 10 (2): 149-153 